\title{
Giambiagi, Fabio e Luiz P. V. Lucas (Eds.) Petróleo: reforma e contrarreforma do setor petrolífero brasileiro (Rio de Janeiro: Elsevier, 2013), 334p.
}

DOI: $10.5935 / 2237-2717.20150008$

Paulo Henrique Martinez

Universidade Estadual Paulista (UNESP)

martinezph@uol.com.br

Assis

Brasil

Recibido: 22 de marzo de 2015

Aprobado: 12 de julio de 2015

Um livro para o debate público. Um questionamento da política setorial de petróleo e gás sob os governos Lula e Dilma Rousseff. Uma legítima disputa ideológica sob o mantra da técnica, gestão e mercado. A notória e melhor caraterística deste volume coletivo é, sem dúvida alguma, a franqueza e a objetividade. Um livro de ideias políticas sinceras.

A tônica da abordagem combina inteligentemente racionalidade econômica e ação do Estado. A fortuna das empresas é a fortuna da arrecadação pública e um Estado racional distribui benefícios sociais, inclusive sob a forma de regulação e de disciplina das forças econômicas e dos interesses privados atuantes no mercado nacional. As identidades políticas são fluídas, os rótulos ambíguos, talvez inúteis: liberalismo, neoliberalismo, socialdemocracia?

Generoso, objetivo, afável, bem informado, analítico, propositivo. São muitos os méritos reunidos no conjunto de textos organizado nas quatro partes em que se distribuem os treze capítulos e as conclusões. São dezessete autores e duas autoras com formação técnica e profissional qualificada, experiência política e administrativa no setor público e privado, agasalhados sob as asas do áspero Prefácio assinado pela emblemática figura-síntese da ciência e da ação do Estado no Brasil recente, o sociólogo e ex-presidente da República Fernando Henrique Cardoso. A querela política apresenta-se, então, já nas primeiras páginas. 0 centro do debate e das disputas reside na exploração das reservas de petróleo em águas profundas no litoral brasileiro, o pré-sal, descobertas em 2007.

A trajetória da Petrobras, a empresa petrolífera estatal brasileira, é examinada no primeiro e único capítulo da Parte I. 0 capítulo vale pela reconstituição histórica e também pelo depoimento pessoal do autor, engenheiro e dirigente da Petrobras. Nas duas partes seguintes o leitor encontra o cotejo entre dois períodos da história brasileira, distinguindo duas eras do petróleo e gás, desde a criação do monopólio estatal e da Petrobras, em 1953.

A primeira é a "era da abertura", compreendida entre 1997 e 2010, quando aquele setor da economia foi regido pela Lei do Petróleo aprovada no primeiro mandato presidencial de Fernando Henrique Cardoso (19951998). Os quatro capítulos da segunda parte do livro estão dedicados ao exame da "reforma legal de 1997" instituída após o fim do monopólio estatal do petróleo, em 1995. A mudança ocorreu sob a "modernização do Estado e da economia no Brasil" promovida por FHC. Um conjunto de reformas que incluiu a privatização de empresas estatais, planos anti-inflacionários, ajuste fiscal, responsabilidade fiscal na administração pública, ausência de reajustes salariais e de contratações no funcionalismo público, amparo financeiros às instituições bancárias, adoção da reeleição aos cargos do Poder Executivo, entre outras inciativas jurídicas e políticas.

Os novos cenários globais anunciados na década de 1990 teriam motivado o governo Fernando Henrique Cardoso a promover o marco regulatório para o setor petrolífero no Brasil. A ampliação da participação acionária, a busca de investimentos e de competividade internacionais teriam lançado a Petrobras em posições de liderança na economia mundial, gerando ainda estímulos à indústria nacional de equipamentos e de prestação de serviços. A criação da Agência Nacional do Petróleo, Gás Natural e Biocombustíveis (ANP) completava o quadro 
institucional na regulação das atividades do modelo de concessões adotado para a exploração e a produção na lei de 1997. Os resultados são avaliados no livro como experiência bem-sucedida, "estratégia vencedora", "reestruturação competitiva do setor" e "sabedoria política" do governo na sua aprovação e implantação nos anos seguintes.

0 segundo período da política do petróleo e gás no Brasil, apontado como "era da incerteza", é examinado na terceira parte. Anunciada como a "essência desta coletânea", agrupa seis capítulos que abordam os momentos posteriores ao novo marco regulatório, aprovado em 2010, último ano do governo Lula. A mudança para o modelo de partilha é entendida como "o grande erro" e as suas razões e consequências concentram as atenções dos autores desses capítulos. Os argumentos percorrem a origem e 0 destino da arrecadação fiscal, dos investimentos públicos e privados, a evocação do livre mercado, o desequilíbrio federativo decorrente da distribuição dos rendimentos petrolíferos, incongruências jurídico-constitucionais, riscos de descapitalização e de desempenho empresarial da Petrobras.

Os dois capítulos finais compõem a quarta e última parte do livro e que engloba as conclusões e propostas para 0 setor. Os capítulos trazem prognósticos da geopolítica mundial do petróleo e do modelo de partilha na exploração e na produção vigente desde 2010. 0 texto final contém a síntese do conjunto dos capítulos e apresenta sugestões para o futuro das políticas no setor de petróleo e gás. Estas recomendam a revisão do caminho trilhado a partir de 2010, envolvendo competitividade, legislação geral e específica, licitações, federalismo, preços e tributação.

0 volume não aponta apenas equívocos e necessidade de correção de erros na política pública para a agenda do petróleo e gás no Brasil. Ele exprime teor de autoelogio, a intenção de dar lições e fundamentos a discursos políticos técnica e eleitoralmente mais eficientes. Aos autores a crise financeira mundial desencadeada em 2008 parece episódio distante, alheio e sem efeito nos rumos das decisões governamentais. Será? A questão ambiental não é referida exceto em pouco mais de uma página no item sobre o licenciamento no terceiro capítulo. Já a polarização nas eleições presidenciais, em 2014, esvaziou a retórica técnico-científica no debate público. A corrupção e o financiamento de campanhas eleitorais identificadas nas diretorias da Petrobras e que levaram ao indiciamento de políticos e empresários - as próprias investigações policiais constataram o fato - remontam aos anos 1990.

Uma vez mais o debate público foi surrado pelas contendas eleitorais e o oportunismo político e partidário. Tornou-se inegável que o poder econômico nas disputas eleitorais ainda constitui um pilar de sustentação da ação do Estado, da manutenção de privilégios e da dominação de classe no Brasil, comprometendo a vigência e 0 alcance da democracia constitucional na atualidade. As seguidas contestações da legitimidade do segundo mandato de Dilma Rousseff dão, hoje, a medida desta fragilidade política. 